\title{
Inovative Design of Mattress by Using TRIZ and QFD Hartomo Soewardi ${ }^{1}$, Ginanjar Sarwo Edhi ${ }^{1}$
}

\begin{abstract}
At this time the need for the design of a product is increased. Mattress is a necessity for every individual to rest. Preliminary studies of the function of the mattress stated that the use of the existing mattress found complaints (too large $72 \%$, less attractive $40 \%, 80 \%$ less flexible, less comfortable $40 \%$ ). Therefore, multifunctional mattress is needed. The purpose of this study is to propose a multifunctional design for a mattress. TRIZ method is used to determine the inventive principles of each attribute and QFD method is used to determine the design parameters of the mattress. Functions that can be developed from a mattress are that it can be folded, it can be a sofa / seating, into the table, flexible /easily removable and as the ironing board. The results of this study shows that the multifunctional mattress design was satisfied the customer feeling and emotion.
\end{abstract}

Keyword-Mattress, TRIZ, QFD, Multifaction, Design

\section{INTRODUCTION}

A $t$ this time the need for the design of a product is increased. Mattress is a necessity for every individual to rest. Preliminary studies of the function of the mattress stating that the use of the existing mattress found complaints (too large $72 \%$, less attractive $40 \%, 80 \%$ less flexible, less comfortable $40 \%$ ). Therefore, multifunctional mattress is needed.

The method which are used in this study are TRIZ and QFD. TRIZ is a problem solving method based on logic and data, not intuition, which accelerates the ability to solve problems creatively. QFD is an attempt by the company in designing and developing products or services in accordance with the voice of customer and combined with the voice of the engineer who is a reflection of the company's technical capabilities to meet the customer requirement.

TRIZ method is used to determine the inventive principles of each attribute and QFD method is used to determine the design parameters of the mattress. The purpose of this study is to propose a multifunctional design for a mattress.

\section{RESEARCH METHOD}

A. Survey

Paper based survey was conducted in this study to identify customer criteria of multifunctional mattress design. Questionnaires were distributed to students boarding in Yogyakarta, which is in the area around the campus which totaled 50. This questionnaire is to identify customer requirement of the mattress, determine the design of the mattress according to customer requirement and validation of the design of the mattress.

\section{B. Application of TRIZ}

TRIZ is a problem solving method based on logic and data, not intuition that accelerates the ability to solve problems creatively [1][2]. The procedure for applying TRIZ are first, select technical problem; second, formulate a physiscal contradiction; third, formulate an ideal solution; fourth, find resources for the solution, making use of the capabilities of TRIZ; fifth, determine "strength" of the solution and choose the best one; sixth, predict the development of the system considered within; seven, analyze the problem and the solution process in order to prevent similar problems [2][3][7]. TRIZ is used to solve the existing problems in the design of this multifunctional mattress.

\section{Application of $Q F D$}

QFD is an attempt by the company in designing and developing products or services in according voice of customer and combined with the voice of the engineer who is a reflection of the company's technical capabilities to meet the customer's wishes[4][5][6]. There are four stages in using QFD, first phase of product planning (house of quality), the second stage of the planning component (part deployment), the third stage of the planning process (process deployment), the fourth stage of the planning of production (manufacturing / production planning) [6][8]. HOQ was used for make the design parameters of the multifunctional mattress. 


\section{Development of The Virtual and Real Prototype}

The objective of the development virtual prototyping is to validate physical design parameters of multifunctional mattress which satisfies user's needs. This study was done by showing the virtual design multifunctional mattress rated by users. A qualitative assessment was conducted by questionnaire to validate the virtual prototyping

\section{E. Statistical Analysis}

The analytical methods used in this research are TRIZ and QFD. TRIZ method is used to analyze about what needs to be done on the multifunctional mattress based on customer requirements. While QFD analyzes on the design parameters to be used in the design of this multifunctional mattress. Analysis of the homogeneity use Stuart-Maxwell test of marginal homogeneity [10]. Final analysis of the differences between the proposed product and the product that already exists used Wilcoxon test[10].

\section{RESUlt AND Discussion}

\section{A. Customer Requirements}

\begin{tabular}{clcc}
\multicolumn{4}{c}{ Table 1. Percentage Of Customer Requirements } \\
\hline No. & \multicolumn{1}{c}{ Customer Requirements } & Total & Percentage \\
\hline 1 & Flexible/ foldable & 46 & $92 \%$ \\
2 & Chair & 42 & $84 \%$ \\
3 & Table & 40 & $80 \%$ \\
4 & Portable/ moveable & 38 & $76 \%$ \\
5 & Ironing Board & 30 & $60 \%$ \\
\hline
\end{tabular}

B. Result of TRIZ

1) Improving Feature

Table 2.Improving Feature

\begin{tabular}{cll}
\hline No. & Attribute & Improving Feature \\
\hline 1 & Flexible/ foldable & Easy Operation (33) \\
2 & Chair & Shape (12) \\
3 & Table & Shape (12) \\
4 & Portable/ moveable & Volume Of Moving Object (7) \\
5 & Ironing Board & Strength (14) \\
\hline
\end{tabular}

2) Worsening Feature

Table 3. Worsening Feature

\begin{tabular}{cll}
\multicolumn{2}{c}{ Table 3. Worsening Feature } \\
\hline No. & \multicolumn{1}{c}{ Attribute } & \multicolumn{1}{c}{ Worsening Feature } \\
\hline 1 & Flexible/ foldable & Shape (12) \\
2 & Chair & Quantity Of Substance (26) \\
3 & Table & Length Of Moving Object (3) \\
4 & Portable/ moveable & Weight Of Moving Object (1) \\
5 & Ironing Board & Stability Of The Object Compotition (13) \\
\hline
\end{tabular}

3) Matrix of Contradictions
Table 4. Contradiction Of Flexible/ Foldable

\begin{tabular}{c|c}
\hline \multirow{2}{*}{ Improving Feature } & Worsening Feature \\
\cline { 2 - 2 } & Shape (12) \\
\hline Easy Operation (33) & $15,34,28$ \\
\hline
\end{tabular}

Table 5. Contradiction Of Chair

\begin{tabular}{c|c}
\hline \multirow{2}{*}{ Improving Feature } & Worsening Feature \\
\cline { 2 - 2 } & Quantity Of Substance (26) \\
\hline Shape (12) & 36,22 \\
\hline
\end{tabular}

Table 6. Contradiction Of Table

\begin{tabular}{c|c}
\hline \multirow{2}{*}{ Improving Feature } & Worsening Feature \\
\cline { 2 - 2 } Shape (12) & Length Of Moving Object (3) \\
\hline \multirow{2}{*}{ Table 7. Contradiction Of Portable/ Moveable } \\
\hline \multirow{2}{*}{ Improving Feature } & Worsening Feature \\
\cline { 2 - 2 } Volume Of Moving Object (7) & Weight Of Moving Object (1) \\
\hline \multirow{2}{*}{ Table 8. Contradiction Of Ironing Board } \\
\hline \multirow{2}{*}{ Improving Feature } & Worsening Feature \\
\cline { 2 - 2 } & $\begin{array}{r}\text { Stability Of The Objects } \\
\text { Compotition (13) }\end{array}$ \\
\hline Strength (14) & $13,17,35$ \\
\hline
\end{tabular}

Table 9. Inventive Principles

\begin{tabular}{|c|c|c|c|c|}
\hline No. & Attribute & Improving Feature & Worsening Feature & Inventive Principles \\
\hline \multirow[t]{3}{*}{1} & Flexible/ foldable & Easy Operation (33) & Shape (12) & Dynamics (15) \\
\hline & & & & Discarding and Recovering (34) \\
\hline & & & & Mechanic Subtitution (28) \\
\hline \multirow[t]{2}{*}{2} & Chair & Shape (12) & Strength (14) & Phase Transition (36) \\
\hline & & & & Blessing in Disguise (22) \\
\hline \multirow[t]{2}{*}{3} & Table & Shape (12) & Length Of Moving & Discarding and Recovering (34) \\
\hline & & & Object (3) & $\begin{array}{l}\text { Merging or Combining (5) } \\
\text { Asymetry (4) }\end{array}$ \\
\hline \multirow[t]{3}{*}{4} & Portable/ moveable & Volume Of Moving Object & Weight Of Moving & Taking Out (2) \\
\hline & & & Object (1) & Copying (26) \\
\hline & & & & Composite Material (40) \\
\hline \multirow[t]{3}{*}{5} & Ironing Board & Strength (14) & Stability Of The Object & The Other Way Round (13) \\
\hline & & & Compotition (13) & Another Dimension (17) \\
\hline & & & & Parameter Changes (35) \\
\hline
\end{tabular}


4) Selected Inventive Principles

1. Flexible/ foldable

Principle 15. Dynamics

Dividing an object or system into parts that capable of cooperating against each other.

2. Chair

Principle 36. Phase Transition

Using a phenomenon that occurs during the transition period (such as changes in volume, the process of disappearing or heat absorption).

3. Table

Principle 34. Discarding and Recovering

Making or removing parts of objects or modify the system or directly modified during surgery.

Principle 5. Merging or Combining

Combining objects or systems that are identical / similar and combining the identical parts to perform parallel operations.

C. Result of $Q F D$

1) House of Quality
Principle 4. Asymmetry

Changing the shape of an object or a system of symmetrical to asymmetrical.

4. Portable/ moveable

Principle 26. Copying

Using an object or a system that much simpler and cheaper.

Copy the concept of creative services in different industries.

Principle 40. Composite Material

Changes some of the raw materials used.

5. Ironing Board

Principle 13. The Other Way Round

Reversing the appropriate actions to solve the problem.

Principle 17. Another Dimensions

Reorientation of the object or system or using the other parts of an object or system.

Table 10. Correlation Matrix of HOQ

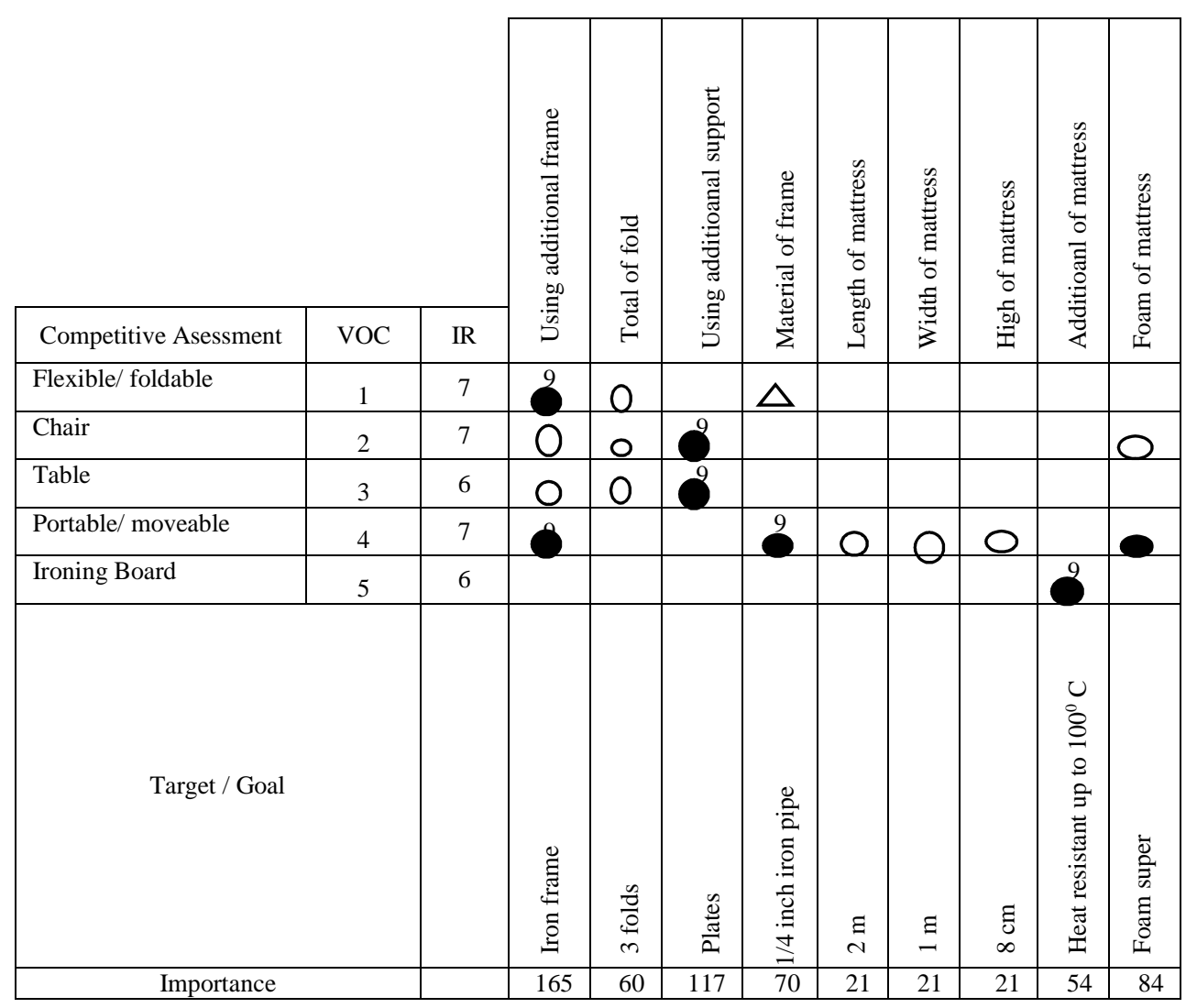




\begin{tabular}{|c|c|c|c|c|c|c|c|c|c|}
\hline \multicolumn{5}{|c|}{ Competitive assesment } & \multirow{2}{*}{ Goal } & \multirow{2}{*}{ Improvement Ratio } & \multirow{2}{*}{ Sales Point } & \multirow{2}{*}{ Row Weight } & \multirow{2}{*}{ Action } \\
\hline 1 & 2 & 3 & 4 & 5 & & & & & \\
\hline & & & & & 5 & 1.25 & & 10,5 & B \\
\hline & & & & & 5 & 1.25 & & 10,5 & B \\
\hline & & & & & 4.5 & 1.13 & & 8,1 & B \\
\hline & & & ( & & 4 & 1.00 & & 7,00 & $\mathrm{C}$ \\
\hline & & & & & 5 & 1.25 & $\Omega$ & 9,00 & B \\
\hline
\end{tabular}

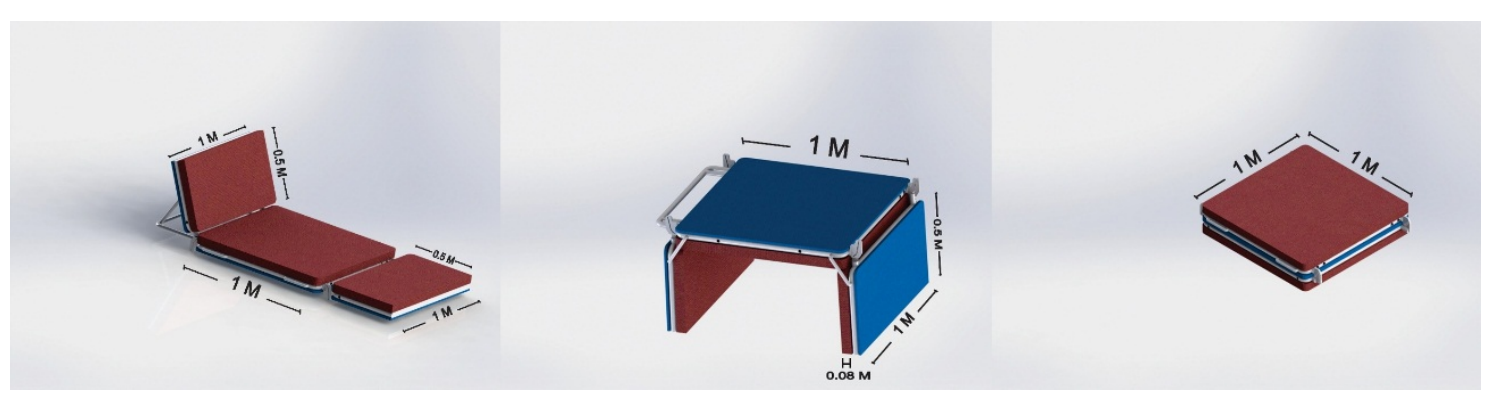

Fig. 1 Design of Multifunctional Mattress

Multifunctional design of mattress has a size of $2 \mathrm{~m} \times 1 \mathrm{~m}$ $\mathrm{x} 8 \mathrm{~cm}$ adapted to the target of processing data using QFD. Materials used framework is $1 / 4$ inch iron pipe welded and connected with the joint so that it can be make some form. The foam which is used is the super foam that is not easily deflated and on the ironing board foam heat resistant up to $100^{\circ} \mathrm{C}$ so it is not easy to melt when used as an ironing board.

\section{Result of Validation \\ 1) Homogeneity Test}

Validate of multifunctional mattress test by Stuart Maxwell test of Marginal homogeneity. The hypotheses were developed as follows:

$\mathrm{H}_{0}$ : There is no significant difference between the consumer criteria and mattress design

$\mathrm{H}_{1}$ : There is a significant difference between the consumer criteria and mattress design

TABLE XII

\begin{tabular}{l|c}
\multicolumn{1}{c}{ RESULT OF MARGINAL HOMOGENEITY } \\
\hline Attribute & $\begin{array}{c}\text { Asymp. Sig. (2- } \\
\text { tailed) }\end{array}$ \\
\hline Flexible/ foldable & 0.109 \\
Chair & 0.378 \\
Table & 0.197 \\
Portable/ moveable & 0.739 \\
Ironing Board & 0.622 \\
\hline
\end{tabular}

Table XII shows that Asymp column. Sig. (2-tailed) the existing number, all were above 0.05 , which means that the proposed design is suitable to the customer requirements of multifunction mattress.

\section{2) Sign Test}

Wilcoxon signed-rank test was used to compare the selected design of multifunctional mattress and the common mattress.
TABLE XIII

HASIL UJI BEDA WILCOXON

\begin{tabular}{l|c}
\multicolumn{1}{c}{ Attribute } & Asymp. Sig. (2-tailed) \\
\hline Flexible/ foldable & 0.000 \\
Chair & 0.000 \\
Table & 0.000 \\
Portable/ moveable & 0.000 \\
Ironing Board & 0.000 \\
\hline
\end{tabular}

Table XIII shows that Asymp column. Sig. (2-tailed) the existing number, all were below 0.05, which means that there is a difference between a regular mattress and mattress multifunctional. The results showed that the respondents chose a multifunctional mattress instead of common mattress.

\section{CONCLUSION}

Based on the result of this research, concluded that functions that can be developed on a mat in accordance customer requirements of multifunction mattress is flexible / foldable, chair, table, portable / moveable and ironing board. Inventive principles of each attribute is Inventive principle which suitable with the attribute of flexible / foldable is principle Dynamics (15) with subprinsip B, Inventive principle which suitable with the attribute of chair is principle Phase Transition (36), Inventive principle which suitable with the attribute of table is principle Discarding and Recovering (34) with subprinsip A, principle Merging or Combining (5) and principle Asymetri (4) with subprinsip A, Inventive principle which suitable with the attribute of portable/ moveable is principle Copying (26) with subprinsip A and subprinsip D, and principle Composite Material (40), Inventive principle which suitable with the 
attribute of ironing board is principle The Other Way Round (13) with subprinsip and principle Another Dimension (17). Design parameters for the design of multifunctional mattres are frame using $1 / 4$ inch iron pipe. Size of this mattress is $2 \mathrm{~m} \times 1 \mathrm{~m} \times 8 \mathrm{~cm}$. Foam used is foam super quality. On the layer for ironing using foam heat resistant up to $100^{\circ} \mathrm{C}$. Marginal homogeneity test result shows that the designs of multifunctional mattress is suitable to the customer requirements with Asymp value. Sig. (2tailed) of the five functions are more than 0.05 . Wilcoxon test results showed the difference between multifunctional mattress and common mattress with the value of Asymp. Sig. (2tailed) of the five functions are less than 0.05.

\section{RECOMENDATIONS}

The future research should investigate more deeply any function that can be developed on a multifunctional mattress and add economic analysis of the multifunctional mattress.

\section{REFERENCES}

[1] Barry, K. Domb, E. \& Slocum, M.S. 2006. TRIZ, what is TRIZ?. TRIZ Journal

[2] Diegel, O. 2004. TRIZ. Creative Industries Conference.

[3] Gadd, K. 2011. TRIZ for engineers : enabling inventive problem solving. Online book

[4] Ginting, M. 2011. Analisa Permasalahan Komponen Tempat Tidur Pasien dengan Metode QFD. Jurnal Austenit Vol. 3 No. 2 $: 1-7$
[5] Hamrah \& Yayah, K. W. 2007. Metode QFD untuk Informasi Penyempurnaan Perakitan Varietas Melon. Jurnal Agribisnis dan Ekonomi Pertanian Vol. 1 No. 2 : 49-54

[6] Ictenbas, B. D \& Erylmaz, H. 2011. Quality Function Deployment As A Strategic Planning Tool. International Journal Of Social Sciences and Humanity Studies Vol. 3 No. 2 ISSN : 1309-8063 : 73-76

[7] Ilevbare, I. Phaal, R. Probert, D. Padilla, A.T. 2011. Integration Of TRIZ And Roadmapping For Innovation, Strategy, And Problem Solving. Centre For Technology Management, University Of Cambridge, UK.

[8] Rahman, A. Supomo, H. 2012. Analisa Kepuasan Pelanggan pada Pekerjaan Reparasi Kapal dengan Metode Quality Function Deployment (QFD). Jurnal Teknik ITS Vol. 1 No. 1 ISSN : 23019271:298

[9] Sari, D.P., Harmawan, A. 2012. Usulan Perbaikan Kualitas Pelayanan Pada Instalasi Rawat Jalan Dengan Metode Servqual dan TRIZ. J@TI Undip Vol VII No.2

[10] Sheskin, D. J. 2004. Handbook of parametric and nonparametric statistical procedure, third edition. Florida : Chapman and Hall/ CRC Press

[11] Stratton, R. Mann, D. \& Otterson, P. 2000. The theory of inventive problem solving (TRIZ) and system-a innovation-a missing link in engineering education. Systematic Innovation

[12] Sulistyo, H. 2011. Implementasi QFD dalam Meningkatkan Daya Saing Pasar Tradisional. Jurnal Siasat Bisnis Vol. 15 No. $2: 158-160$

[13] Suseno, A., Hartono, M. \& Surjani, R.M. 2013. Aplikasi Integrasi Kansei Engineering dan Metode TRIZ Pada Layanan Villa Nunia, Bali. Jurnal Ilmiah Mahasiswa Universitas Surabaya Vol.2 No.1

[14] Wiyogo. Surachman. Soenoko, R \& Setyanto, N, W. 2013. Integrasi Servqual dan Quality Function Deployment untuk Pengukuran Kualitas Layanan. Jemis Vol. 1 No. 1 ISSN : 2338$3925: 21-22$

[15] Zhang, Jun., Kay Chuan Tan, dan Kah Hin Chai, (2003). 40 Inventive Principles with Applications In Service Operation Management 